\title{
Glocalization of Intangible Cultural Heritage: Strengthening Preservation of Indonesia's Endangered Languages in Globalized World
}

\author{
$1^{\text {st }}$ Iyan Septiyana \\ Department of International Relations \\ Universitas Katolik Parahyangan \\ Bandung, Indonesia \\ senyan@ymail.com
}

\author{
$2^{\text {nd }}$ Defbry Margiansyah \\ Global Studies Programme \\ Albert-Ludwig-Universität Freiburg \\ Freiburg, Germany \\ defbry@yahoo.com
}

\begin{abstract}
The negative impact of globalization affects the very existence of cultural identities including local languages. Indonesia, multilingual state with more than 700 local languages, encounters such impact where a number of its languages are increasingly endangered, even some of them already dead. This paper is intended to identify some issues faced by the government and its policies to preserve its vernacular languages. In the final section, we suggest the concept of glocalization as important understanding to expand actors' viewpoint in preserving local languages from endangerment and extinction, as well as attempts to contribute some of the ideas substantiating the preservation effort.
\end{abstract}

Keywords-globalization, glocalization, endangered language, language policy, Indonesia

\section{INTRODUCTION}

Globalization has generated the borderless world where social interaction among distinctive cultural identities is inevitably intensified supported by technologies' advancement. It also affects the existence of languages as cultural identity and human rights. Ironically, the data shows that spoken languages in the world have dropped from 14,500 into less than 7,000 in 2000, some linguist predicts that current existing language about $50-90 \%$ will disappear by the end of the 21 st century [1]. This fact has demonstrated that preservation of local languages is undoubtedly fundamental and also means protection of nations from loss of identities and culture.

Indonesia is a multicultural country, where the society consists of more than 1000 different ethnic groups with its languages. To unify, Bahasa Indonesia is employed as the mode of inter-ethnic communication as means to integrate its large diverse population and to connect its societies across the country. While the local languages are used less formally than national one, the extensive use of Bahasa Indonesia tends to neglect local languages in which their speakers have been shifting the use of existing languages of their place of origin to Bahasa Indonesia, which is considered as more useful to communicate in the public sphere and, more crucially, it has a more value to be a social capital.

Recalling that the local languages are increasingly at risk of extinction. This fact raises the question of why the government of Indonesia failed to appropriately preserve its endangered local languages in the age of globalization. And, why the national authority is unable to turn the globalization process as an opportunity to corroborate its preservation attempt concerning such languages more extensively? What the emerging problems challenges to achieve the more appropriate preservation, which includes the most vulnerable local languages in Indonesia?

This paper aims to reach a satisfactory answer to such questions by combining the theoretical and empirical elaboration in analyzing the problem and generating the suggestion. To that end, we will employ the concept of glocalization to provide new understanding of the importance of diverse local languages for a nation in encountering globalization, which tends to be more understood as the threat rather than opportunities for development of any respect.

\section{FROM SHIFTING TO ENDANGERED: REALITY OF INDONESIA'S VERNACULAR LANGUAGES}

Based on 2011 data from BPS (Statistic Countermeasures Agency), the using of mother tongue in the home environment is about 79.5 percent [2]. The rest is using national language and mastering foreign dominant languages. It describes that many ethnic people in Indonesia are shifting their mother tongue to other languages. According to Crystal [3], the language shift from one to another because to get the better opportunity such as a job or social circles such as educational system, media presence, and the nature politic pressure can be a major cause of a language to be endangered or death. According to Fisherman $[4$, p. 3], the shift will halt the transmission of the previous language that will influence the vitality of a language. Gradually, intergenerational teaching process on local languages will decrease and the existence of the language will be threatened.

Grenoble [5] and Herbert [6] identified, five factors that make a language to be endangered: 1) economy, the poverty in rural areas make human migrate to other more promising city or areas (urbanization) 2) cultural domination: dominant using of a language in literature and education system that marginalizes local languages (westernization-framed globalization [7, p. 51]); 3) Political aspect, i.e. education policies that exclude a language; 4) historical, colonization or boundary dispute in an area then an ethnic group rises and become a dominant; and 5) attitudinal: a minority language associated with poverty, 
illiterate and dominant language associated with progress. These tendencies can be seen clearly in the local social dynamics in Indonesia, particularly in case of increasingly uneven development of Indonesia that centralized in one certain area. Some cases will be elaborated in the section below.

The Indonesian vernacular languages is uncertain countless, some different data shows a different number: 719 vernacular languages (Summer Institute Linguistic/SIL, 2017); based on its vitality there are 143 vernacular languages (UNESCO); almost 2.500 local languages (National Population Census 2010); while Badan Bahasa recorded 652 local languages exclude dialect and sub-dialect from 2.452 observation area. But only thirteen vernacular languages that have more than one million speakers, those are Javanese, Batak, Bali, Bugis, Madura, Minang, Rejang Lebong, Lampung, Makassar, Bima dan Sasak. Year by year the speaker of the rest languages are decreasing, moreover become endanger or extinct such as Tandia language from Mbakawar tribe, Meyah, Mpur, Dunser and Karondori from West Papua; Moksela, Palumata, Kayeli and Hukumina are extinct, while eight other languages are in endangered status [8].

Generally, two factors that make local languages in a country abandoned by its speakers. First, internal factor such as government official language policy: In Indonesia, official language policy have a negative impact to indigenous languages, which young Javanese and Batak speakers dropped from 1980-1990, the young speaker changed their first language to Bahasa Indonesia. Also according to Hajek in Maluku and West Papua language endangerment situation caused by official language policy and religious organization that more favored using Bahasa were more evident, some of them were dead since 1980 such as Hoti, Kamarian, and Batumerah. And the speakers of other languages is less than 500 speakers [9]. Official language policy at national level diminishes the economic opportunity of local languages because those only used in intraethnic communication and local events. For instance, the tribe of Moi and Inanwatan in West Papua in 1993 didn't use their language and shifted to Bahasa since the presence of logging companies in their region [10]. Second is an external factor that characterized by extensive use of English as the standardized language of social interaction in the globalization era. The standard of English or other dominant languages in globalization will genocide other subordinate languages include local languages. As stated by Tsui and Tollefson that the technology and English are two inseparable skills in globalization [11]. Nowadays, youth Indonesia more prefers to use English in their daily communication to be regarded as smarter, more intelligent, and to show their social distinction. The shift of Bahasa Indonesia to English in daily communication gradually will threaten not only local languages in Indonesia but also Bahasa Indonesia as the national language.

Vernacular or local languages in Indonesia are protected by national constitutions such as Law No. 24/2009. It stated the guarantee of Bahasa Indonesia as the national language and the right of the existence and development of the vernacular languages. In 2016 the Vernacular Language Congress of Nusantara resulted from the skeptical view that the constitution does not specifically regulate technically how to protect local languages [12]. From 72 articles of the constitution, there are 3 articles mentioning the using of local language as a complement in product information (article 37) and public service (article 38 ), and in mass media for a special purpose (article 39). While the development, cultivation, and protection (article 42) is the obligation of the local government under the coordination of Language Institution and regulated in government regulation (GR). Some other regulations such as GR no. 57/2014, regulation of the Minister of Home Affair no. 40/2007 stated that the preservation of local languages is obligatory in which local governments must be conducted. But, until 2017 only some of the local authorities have implemented the preservation such as North Sumatera's government that regulates local language and literature preservation, along with its sanction to force implementation [8].

Moreover, Language Institution (Balai Bahasa) is an agency responsible to manage the preservation of local languages in Indonesia. It is established in 1948 to manage the development of national language and local languages, under the Ministry of Cultural and Education. Main tasks are to develop the a national language, but the focus to endangered languages is insufficient. This institutional fact along with other problems explained earlier is fundamentally major hindrances for the government's effort to revitalize ways of endangered languages preservation.

The tendency of the institution which less concern in developing local languages than national language will make Bahasa Indonesia become the internal threat to local languages. Historically why Bahasa Indonesia accepted as the national language because it was neutral and not threating to the identity of other ethnics and local languages. Instead of shifting local languages, Bahasa Indonesia gets some influences from local languages such as Minangnese, Javanese, Sundanese, etc. Thus by enabling to adopt other vernacular, Bahasa Indonesia is nation-widely accepted as a unifying language for multilingual societies [13].

Nevertheless, Danu Hurip Ismadi stated the Language Institution to preserve and to protect local languages as state is running five programs: (1) language mapping, is inventory and identification of local languages program by determining number, variant, and deployment of local languages to group language kinship; (2) vitality observation, is measuring the existence and vitality of a language in social context by calculating total speaker, sphere of using, documentation, learning process, and new media challenge. And the result will identify some criteria: extinct (zero speakers), severely endangered (the speaker ranging from 40 years old above only), endangered (the speaker ranging from 20 years old above), eroding (not spoken by the entire of a tribe only small number of it), stable but threatened (spoken by entire of the tribe, but the tribe is less or/ and less used by tribe), safe (not threatened, spoken by the entire of a tribe with high population). Those result will determine the next step whether conservation, revitalization or both; (3) conservation, is program to preserve, to protect and to keep safe a language by widening the information access that might be lost when the language is ruinous or extinct through compiling phonology, morphology, syntax and character system [8].

Therefore, the next generation can review the document to learn the language; (4) revitalization, is the program to revive the language using which threatened become language loss or 
death by nurturing the rest speaker in order to enhance the user through the learning system in the native community; and (5) language registration, is the program to register the protection results (conservation and revitalization) about language and literature (music, audio, video, transcript) that documented in online network system application. Another side, the preservation of local language is the obligatory of local government who must take the effort to develop and protect local languages [8].

\section{Glocalization AS A ESSENTIAL VIEW FOR PRESERVATION}

For many, globalization causes detrimental consequences for local culture preservation due to its embedded force of Westernization, Americanization, or McDonaldization [27]. It exclusively challenges the existence of local cultures, seen as obstacles to western-modeled modernization, through infusing western culture to the rest of localities. In contrast, the concept of glocalization views that global/cosmopolitan-local antagonism is no longer relevant due to interaction among distinctive local cultures is increasingly globalized regardless of their size or scale. This idea views that global and local milieu are integral, interconnected, and interdependent to one another, where global aspects basically are reconstituted by the sense of localities in many respects [28]. Glocalization should be understood as a way to provide the process of institutionalization enabling global creation of locality through which universal localization processes are guided by formal international institution [29]. Therefore, such concept offers the broader lens to understand that globalization is not a singular process (global westernization) and a project of western imperialism, but it is multidimensional and -directional processes where the co-existence between universalcosmopolitan and particular-local cultures is very likely to materialize. We assume that glocalization is valuable conception to substantiate the strategy of preservation attempt to protect local cultures and heritages against western dominance.

By viewing global dynamics through glocalization lens, the attempt of preservation would utilize global ways to preserve endangered languages but still maintain their very existence from the radical change like shifting language. Then preservation strategy initiated by linguistic communities, emphatic civil societies, and even government agencies, can adopt more advanced means of interaction and communication such as information technologies, media, global institutions, to attract global awareness on the condition faced by endangered local languages in their home countries. This way, in turn, would help local communities to aspire and share thoughtfulness against the marginalization of their cultures and languages in either domestic or global audiences, but also give them a hand related to technical expertise and know-how in safeguarding endangered languages.

Furthermore, more important steps that state and non-state actors require to conduct so as to strengthen preservation of endangered languages in the postcolonial countries are these progressive attempts. First, following Rasmussen [30], we have to overcome our inferior mentality toward western or other foreign cultures and begin to proud of what intangible cultural heritages are, as it has a meaningful value that neglected by "modern" society. Such way can be done through the education system, childhood to the highest level, which gives bigger roles of local culture and languages in shaping youth's knowledge, insight, and perception toward their own identity. This attempt needs openness, visionary, innovative, assertiveness from respective actors in grappling with endangered languages problem. Second is the effort to bring folklore, local art and literature back in education and public spheres [31], like using endangered languages in a poem, music, and art performance independent of industry. Such an attempt would facilitate the state effort to institutionalize and bring them an issue of intellectual property rights. The third is the emphasis on the importance of research on local languages in the policy formulation, where wider population have to urge the government to fully encourage and adopt them in the policymaking process so as to generate feasible and implementable efforts (not "business-as-usual" policies) in tackling the problem. These all are fundamental in addition to the preservation of endangered languages [32].

\section{CONCLUSION}

In the context of globalization, the underlying factors of government's failure to preserve its endangered local languages are: the lack of optimization in using globalization channels such as media industry (TV programs, internet video channels and mobile application) to raise the awareness, concern, infuse pride feeling and respect of local value cultures to Indonesian society; less work with non-state actors such as NGO, INGO, CSO, media owner that concern with education and the issue of endangered languages. The inability of national authority to turn globalization as an opportunity caused by the selective preservation of local cultures that only become commodities which has economical profit, local languages as an intangible culture is excluded. The emerging problems challenge to achieve more appropriate preservation of local cultures including its languages are state simplification on the complex social problem in local society through standard measures; privileging dominant culture or selective preservation; commodifying economically profitable cultures. Thus, glocalization should be regarded as attempts to strengthen the preservation of endangered local languages in Indonesia.

\section{ACKNOWLEDGMENT}

For sisters and brothers throughout the country whose linguistic identitiy is at risk of extinction and marginalized. Hopefully, may the spirit of Bhineka Tunggal Ika bring you out of predicament and misery.

\section{REFERENCES}

[1] M. B. Steger, Globalization: a very short introduction. Oxford; New York: Oxford University Press, 2003.

[2] Liputan6.com, (Board of Language: 13 Vanished Language, 9 critical, 15 about to vanish) "Badan Bahasa: 13 Bahasa Punah, 9 Kritis, 15 Terancam Punah," liputan6.com. [Online]. Available: http://www.liputan6.com/lifestyle/read/2855842/badan-bahasa-13bahasa-punah-9-kritis-15-terancam-punah. [Accessed: 31-Mar-2018].

[3] D. Crystal, Language Death. New York: Cambridge University Press, 2000 . 
[4] P. K. Austin and J. Sallabank, "Introduction," in The Cambridge Handbook of Endangered Languages, New York: Cambridge University Press, 2011.

[5] L. A. Grenoble, "Language ecology and endangerment," in The Cambridge Handbook of Endangered Languages, New York: Cambridge University Press, 2011, pp. 27-43.

[6] W. Harbert, "Endangered languages and economic development," in The Cambridge Handbook of Endangered Languages, New York: Cambridge University Press, 2011, pp. 403-422.

[7] J. N. Pieterse, Globalization and Culture: Global Mélange. Maryland: Rowman \& Littlefield, 2009.

[8] H. D. Ismadi, (The Policy of Preserving local Language in the Cultural Change in Indonesia) "Kebijakan Pelindungan Bahasa Daerah Dalam Perubahan Kebudayaan Indonesia," Badan Pengembangan dan Pembinaan Bahasa, 2017. [Online]. Available: http://badanbahasa.kemdikbud.go.id/lamanbahasa/artikel/2542/kebijakan -pelindungan-bahasa-daerah-dalam-perubahan-kebudayaan-indonesia. [Accessed: 31-Mar-2018].

[9] J. Hajek, "On the Edge of the Pacific: Indonesia and East Timor," in Language diversity in the Pacific: Endangerment and Survival, Tonawanda: Multilingual Matters Ltd, 2006, pp. 121-130.

[10] H. Steinhauer, "The Indonesian language situation and linguistics: Prospects and possibilities," Bijdr. Tot Taal- Land- En Volkenkd., vol. 150, no. 4, pp. 755-784, 1994.

[11] H. K. Tong and L. H. Cheung, "Cultural identity and language: a proposed framework for cultural globalisation and glocalisation," J. Multiling. Multicult. Dev., vol. 32, no. 1, pp. 55-69, Feb. 2011.

[12] Republika Online, (Congres of Language Emerges The Bandung Declaration) "Kongres Bahasa Hasilkan Deklarasi Bandung," Republika $\begin{array}{llll}\text { Online, 05-Aug-2016. } & \text { [Online]. Available: }\end{array}$ http://republika.co.id/berita/koran/kesra/16/08/05/obfcs739-kongresbahasa-hasilkan-deklarasi-bandung.

[13] S. Paauw, "One Land, One Nation, One Language: An Analysis of Indonesia's National Language Policy," in University of Rochester Working Papers in the Language Sciences, 2009.

[14] J. C. Scott, "Seeing like a state: How certain schemes to improve the human condition have failed". New Haven: Yale University Press, 1998.

[15] T. Loo, "High Modernism, Conflict and the Nature of Change in Canada: A Look at 'Seeing Like a State," Can. Hist. Rev., vol. 97, no. 1, pp. 34-58, 2016.

[16] T. M. Li, The Will to Improve: Governmentality, Development, and the Practice of Politics. Duke University Press, 2007.
[17] J. Tomlinson, "Globalization and cultural identity," in The Global transformations reader: an introduction to the globalization debate, Cambridge: Polity, 2003, pp. 269-277.

[18] M. Castells, End of millenium. Chichester; Malden (MA): WileyBlackwell, 2010.

[19] F. Teguh, "Resources efficiency, safeguarding natural and cultural resources: sustainable tourism policy and practices. Implementation and challenge for initiative and programs," Papua New Guinea, 21-Mar2017.

[20] World Travel \& Tourism Council, "Travel \& Tourism Economic Impact 2017: Indonesia," World Travel \& Tourism Council, London, Mar. 2017.

[21] R. Shepherd, "Commodification, culture and tourism," Tour. Stud., vol. 2, no. 2, pp. 183-201, Aug. 2002.

[22] M. Heller, "Globalization, the new economy, and the commodification of language and identity," J. Socioling., vol. 7, no. 4, pp. 473-492, Dec. 2003.

[23] A. Appadurai, "Introduction: commodities and the politics of value," in The social life of things: commodities in cultural perspective, New York: Cambridge University Press, 1986, pp. 3-63.

[24] A. Mooney and B. Evans, Globalization: The Key Concepts. Routledge, 2007.

[25] J. S. Bell, "The Politics of Preservation: Privileging One Heritage over Another," Int. J. Cult. Prop., vol. 20, no. 4, pp. 431-450, 2013.

[26] UNESCO, "Indonesia - intangible heritage - Culture Sector - UNESCO." [Online]. Available: https://ich.unesco.org/en/state/indonesiaID?info=elements-on-the-lists.

[27] G. Ritzer, “The 'McDonaldization' of Society," J. Am. Cult., vol. 6, pp. 100-107, Jun. 2004.

[28] R. Robertson, "Glocalization: Time-space and homogeneityheterogeneity," in Global modernities., London: Sage, 1997, pp. 25-45.

[29] M. Featherstone and S. Lash, "Globalization, Modernity and the Spatialization of Social Theory: An Introduction," in Global modernities., London: SAGE, 1997, pp. 1-24.

[30] H. Rasmussen, "Protecting the Heritage of Indigenous People," in Globalization and Intangible Cultural Heritage: Opportunities, Threats and Challenges, Tokyo, 2005.

[31] K. Iwabuchi, "Transnational Media Culture and the Possibility of Transgressive Dialogues," in Globalization and Intangible Cultural Heritage: Opportunities, Threats and Challenges, Tokyo, 2005.

[32] A. A. Arantes, "Global Opportunities for Intangible Heritage: New Challenges for Local Lives," in Globalization and Intangible Cultural Heritage: Opportunities, Threats and Challenges, Tokyo, 2005. 